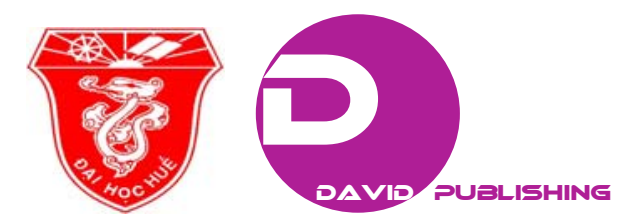

\title{
Nutrient Mass Balances in Intensive Shrimp Ponds with a Sludge Removal Regime: A Case Study in the Tam
}

\section{Giang Lagoon, Central Vietnam}

\author{
Huy Van Nguyen ${ }^{1,2}$ and Morihiro Maeda ${ }^{1}$ \\ 1. Graduate School of Environmental and Life Science, Okayama University, 3-1-1 Tsushima-Naka, Kita-Ku, Okayama 700-8530, \\ Japan \\ 2. Faculty of Fisheries, College of Agriculture and Forestry, Hue University, 102 Phung Hung Street, Hue City, Vietnam
}

\begin{abstract}
Understanding the sources and sinks of nutrients is of significant importance for better management of pond water quality and the environmental impact of aquaculture. The objective of the present study was to estimate the nutrient mass balances of four intensive shrimp (Litopenaeus vannamei) ponds in Tam Giang Lagoon, Central Vietnam, using a sludge management regime. The nutrient budgets were calculated based on the sources and sinks of nutrients in the ponds over a period of $49 \mathrm{~d}$. The input sources of $\mathrm{N}$ and $\mathrm{P}$ were mainly shrimp feed, which accounted for more than $90 \%$. Shrimp harvesting was the largest sink of N (37.5\%), but not of $\mathrm{P}(18.3 \%)$. Almost $30.4 \% \mathrm{~N}$ and $16.9 \% \mathrm{P}$ of input were not accounted for the measured losses. While the smallest proportion of $\mathrm{N}$ $(18.9 \%)$ was retained in sludge, the largest amount of $\mathrm{P}$ was accumulated in sludge $(53.2 \%)$. The farm was operated without water exchange, so ponds gained only $1.9 \% \mathrm{~N}$ and $4.2 \% \mathrm{P}$ from water intake. The pond lost about $13.2 \% \mathrm{~N}$ and $11.6 \% \mathrm{P}$ from discharge water. Production of $1 \mathrm{~kg}$ shrimp needed $84.9 \mathrm{~g} \mathrm{~N}$ and $26.1 \mathrm{~g}$ P from total input sources and discharged $47.3 \mathrm{~g} \mathrm{~N}$ and $16.0 \mathrm{~g}$ P to the environment. Environmental losses of nutrients were lower or intermediate, when the loads were expressed in both $\mathrm{kg} / \mathrm{ha} / \mathrm{cycle}$ and $\mathrm{kg}$ of $\mathrm{N}$ or $\mathrm{P}$ per ton of shrimp produced. Furthermore, the environmental impacts of aquaculture are controlled from the system.
\end{abstract}

Key words: Shrimp pond, L. vannamei, nutrient mass balances, N, P.

\section{Introduction}

Rapid development of shrimp farming has generated considerable concerns about the effects of aquaculture pond effluents on nearby aquatic ecosystems due to increasing nutrient input [1]. Higher stocking densities of shrimp in ponds usually increases feeding rates with a concurrent increase in accumulation of sludge [2], which exacerbates problems of water quality and sediment deterioration. The water quality in ponds varies with the intensity of farming [3], and the deterioration of water quality in intensive culture ponds has been mainly related with organic matter, total nitrogen and inorganic phosphorus [4]. The feed ration is estimated from the

Corresponding author: Morihiro Maeda, professor, research field: environmental science. shrimp biomass in ponds, and intensive culture requires more feed input. On the other hand, the growth of shrimp in an extensive system depends fully on natural food organisms, and in semi-intensive culture systems, both supplemental feed and natural food organisms are used [5].

According to International Union for Conservation of Nature (IUCN \& IISD) [6], shrimp farms on sandy land utilize unproductive land and offer opportunities for development of methods of shrimp disease management. However, one of the biggest challenges for shrimp culture is how to simultaneously overcome environmental and economic concerns by implementing management strategies to reduce water contamination and sludge [7], because large amounts of nutrient inputs are lost to the environment $[1,8]$. In response to this, enhancing nutrient recovery through 
the shrimp harvest and reducing environmental problems should be applied to intensive shrimp culture. Removing sludge accumulated at the bottom is considered to be an effective technique that can reduce up to $67 \%$ of $\mathrm{N}$ added as feed [9]. Furthermore, pond effluents and sludge disposal need much more attention for sustainable aquaculture development, because sludge removal takes materials out of the ponds before they are mineralized and release inorganic nutrients into the water column. Sludge removal coupled with water exchange methods is acceptable in reducing the nutrient concentration and risk of shrimp diseases. Previous works have presented methods to improve water quality and productivity of intensive shrimp ponds. So far, very few reports have described the nutrient mass balances in aquaculture on sandy lands that may have different pond bottom characteristics, especially in ponds with a sludge removal regime.

Nutrient mass balances that account for all inputs and outputs should be examined to assess environmental impacts of aquaculture [10, 11]. Many studies have calculated nutrient mass balances in extensive shrimp ponds [12], semi-intensive ponds [8, $10,11]$ and intensive ponds [7, 13], while, the authors need to elucidate the nutrient budgets in the system for sustainable development. So, the objective of the present study was to estimate the nutrient mass balances for intensive shrimp culture in Tam Giang Lagoon, Central Vietnam, using a sludge management regime.

\section{Materials and Methods}

\subsection{Study Area Description and Pond Management}

Tam Giang Lagoon, located in Central Vietnam, is the largest lagoon in Southeast Asia with a total surface area of 22,000 ha [14]. Aquaculture in the lagoon has been developed since the 1970s, and shrimp culture began in the early 1990s. It quickly became a very important economic sector at the end of the 1990s and early 2000s. Farming of L. vannamei in
Central Vietnam is more intensive $(8 \%)$ than in other regions of the country [15]. The C.P. Group, belonging to the Charoen Pokphand Group of Thailand, has invested in L. vannamei shrimp farming on sandy land located in the North part of the lagoon (Fig. 1), Thua Thien Hue Province, Vietnam, since 2011. The shrimp farm has an area of 180 ha in total for industrial shrimp production. The first shrimp production cycle was operated in the spring from March to May 2013 (49 d). Before being transferred to grow-out ponds, post-larvae (PL) were reared with a density of $8,000 \mathrm{PLs} / \mathrm{m}^{3}$ in a $300 \mathrm{~m}^{2}$ pond in a greenhouse to the size of approximately 2,000 larvae $/ \mathrm{kg}$ in order to minimize mortality and to reduce the grow-out culture period. Seawater was pumped directly from the sea into the pretreatment pond, and mixed with fresh groundwater to get a salinity of 28-30 ppt. Intake water was delivered to the ponds through a network of plastic pipes. L. vannamei shrimp were cultured at two sub-farms, A and B, consisting of 59 grow-out ponds; sub-farm $\mathrm{C}$, rearing ponds in a greenhouse and sub-farm $\mathrm{D}$, under construction for grow-out ponds. Four grow-out ponds at sub-farm A were randomly selected to monitor water and sludge quality and calculate nutrient mass balances. An average stocking density of shrimp in four ponds was $70 \mathrm{PLs} / \mathrm{m}^{2}$. Characteristics of ponds used for mass balance estimation was described in Table 1. Shrimp were fed four times per day (07:30, 12:00, 17:00 and 22:00) with $40 \%$ crude protein commercial diet of C.P. shrimp feed [16]. The initial feeding rate was $9.5 \%$ of the biomass of each pond with adjustment according to apparent consumption through feeding trays. The daily rations were decreased to $1.5 \%$ of biomass at harvesting phase.

Fig. 2 shows the layout of the ponds used in the present study. Pond bottoms and dikes were lined with high-density polyethylene (HDPE) film to prevent water loss through seepage. Each pond had an average area of $0.43 \mathrm{ha}$, a depth of $1.4 \mathrm{~m}$, and six electric aerators (12 horsepower (HP)) arranged to circulate the flow in the pond. 

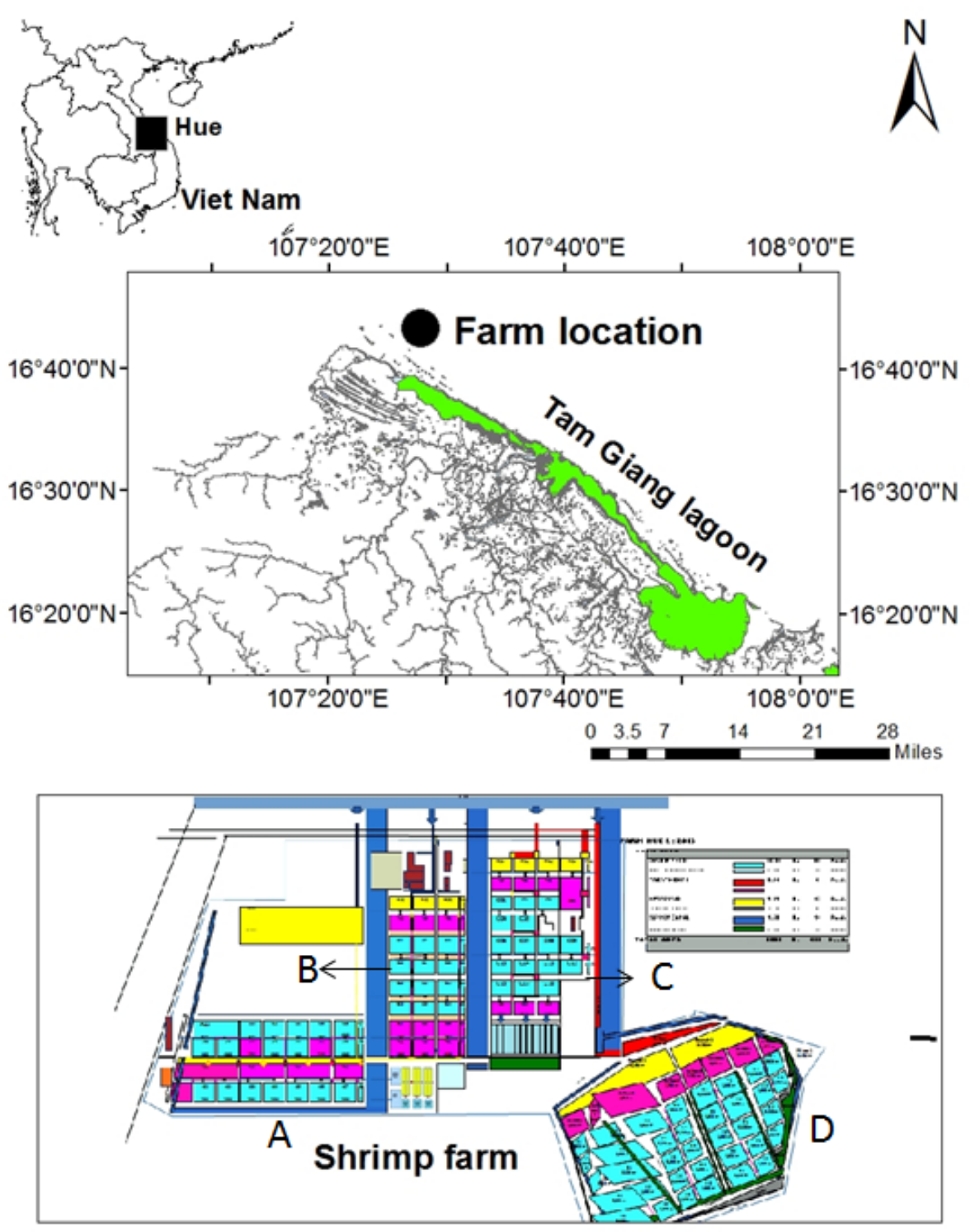

Fig. 1 Shrimp farm location.

A, B are sub-farms for grow out ponds, $\mathrm{C}$ is sub-farm in greenhouse for post-larvae rearing, and $\mathrm{D}$ is under construction for grow out.

Table 1 Characteristics of ponds for nutrients mass balance estimation.

\begin{tabular}{llllllll}
\hline Ponds & $\begin{array}{l}\text { Density } \\
\left(\mathrm{No} . \mathrm{m}^{2}\right)\end{array}$ & $\begin{array}{l}\text { MBW } \\
(\mathrm{g})\end{array}$ & $\begin{array}{l}\text { Survival rate } \\
(\%)\end{array}$ & $\begin{array}{l}\text { Yield } \\
(\mathrm{kg} / \mathrm{ha} / \text { cycle })\end{array}$ & FCR & $\begin{array}{l}\text { Cultural } \\
\text { period (days) }\end{array}$ & $\begin{array}{l}\text { Feed used } \\
(\mathrm{kg} / \mathrm{ha} / \mathrm{cycle})\end{array}$ \\
\hline 1 & 70.0 & 15.9 & 64 & $7,111.1$ & 1.17 & 45.0 & $9,386.7$ \\
2 & 71.0 & 10.0 & 68 & $4,828.0$ & 1.28 & 53.0 & $6,952.3$ \\
3 & 71.0 & 15.2 & 72 & $7,745.5$ & 1.45 & 47.0 & $12,625.1$ \\
4 & 68.0 & 17.9 & 70 & $8,500.0$ & 1.47 & 51.0 & $14,025.0$ \\
Mean & $70.0 \pm 1.4$ & $16.2 \pm 3.3$ & $69.0 \pm 3.4$ & $7,046.1$ & $1.34 \pm 0.2$ & $49.0 \pm 3.7$ & $10,747.3$ \\
\hline
\end{tabular}

MBW: mean body weight, FCR: feed conversion rate = dry weight of feed/wet weight of shrimp harvest.

In this way, sludge accumulation from uneaten feed, feces, detritus, suspended solids and dead organisms was gathered in the center of the ponds, where a drain was placed. Effluent and sludge were physically removed from the pond bottom by polyvinyl chloride (PVC) pipe lines underground connected the center of 


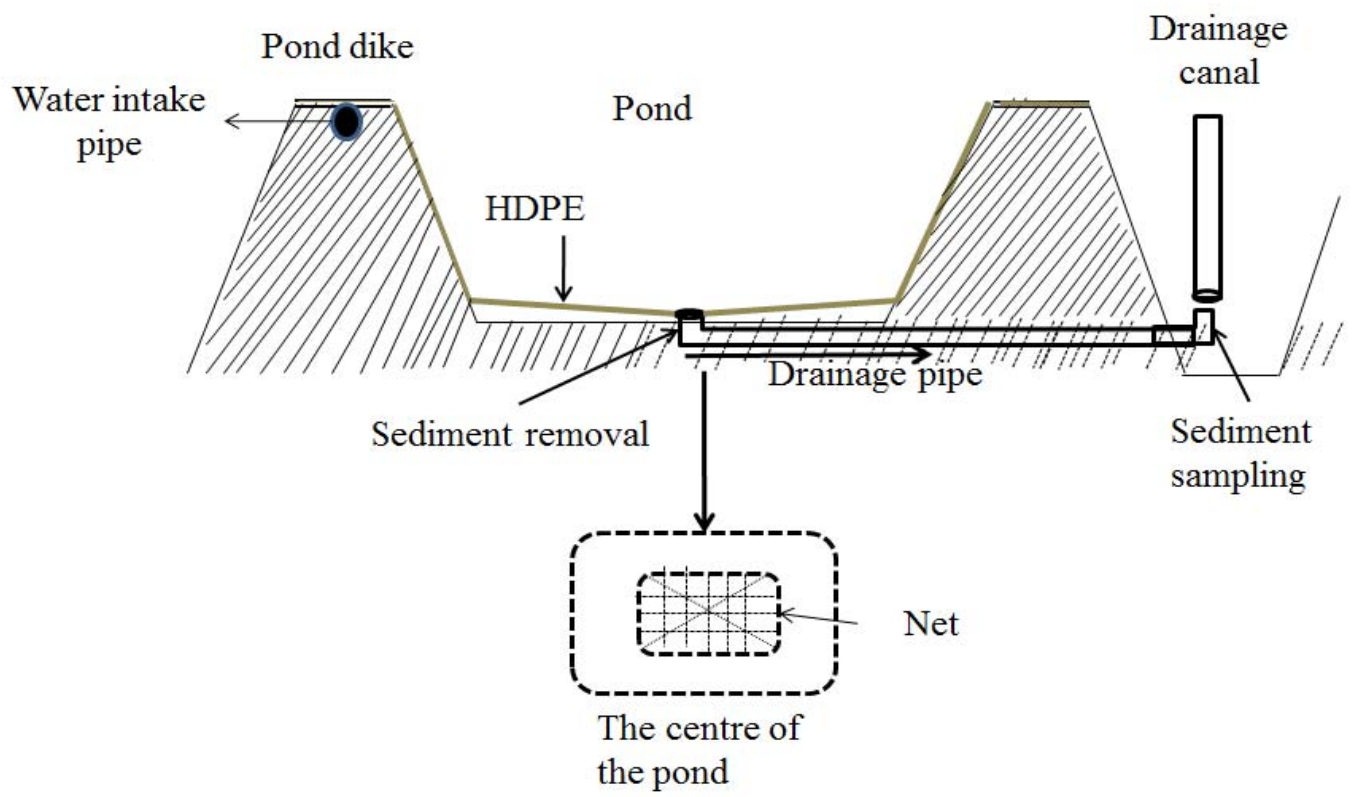

Fig. 2 Pond layout using sludge management regimes.

the ponds to an effluent canal at 20,30,40, and $49 \mathrm{~d}$ after larvae being stocked. To prevent shrimp leaving from the ponds during sludge removal, the central drain was equipped with a screen rack, an overflow mesh weir and a drain valve. This method has the advantage of allowing removal of the sludge and cleaning of the pond bottom flexibly throughout the culture period. An automatic feeding technique is used to deliver commercial feed to shrimp.

\subsection{Sampling and Analytical Methods}

Pond water samples were taken weekly from each pond at $20 \mathrm{~cm}$ below the water surface according to the method of Jackson et al. [7]. The intake water samples were collected before they entered the ponds, while the discharge samples were obtained inside the ponds before sludge was removed. The "initial" samples were those collected immediately before post-larvae stocking, and the samples collected during harvesting phase were designated as "final". Triplicate sludge samples were collected at the end of the pipe outside the pond in the drainage canal, and the water content of sludge was calculated after being dried for $24 \mathrm{~h}$ at $105^{\circ} \mathrm{C}$.
Water samples were filtered through a $0.2 \mu \mathrm{m}$ filter (DISMIC-25AS, Advantec) to determine $\mathrm{NH}_{4}-\mathrm{N}$, $\mathrm{NO}_{3}-\mathrm{N}$, and $\mathrm{PO}_{4}-\mathrm{P}$ concentrations. An unfiltered 10 $\mathrm{mL}$ water sample and $2 \mathrm{~mL}$ reagent of $\mathrm{NaOH}+$ $\mathrm{K}_{2} \mathrm{~S}_{2} \mathrm{O}_{8}$ for total nitrogen (TN) or $2 \mathrm{~mL}$ reagent of $\mathrm{K}_{2} \mathrm{~S}_{2} \mathrm{O}_{8}$ for total phosphorus (TP) were digested at $120{ }^{\circ} \mathrm{C}$ for $30 \mathrm{~min}$, and the product $\left(\mathrm{NO}_{3}-\mathrm{N}\right.$ or $\left.\mathrm{PO}_{4}-\mathrm{P}\right)$ was analyzed for TN or TP [7]. The contents of TN in sludge samples and shrimp feed were analyzed by the dry combustion method using a CN Corder (MT-700, Yanaco, Japan). Approximately $1 \mathrm{~g}$ of air-dried sludge was digested with sulfuric acid and hydrogen peroxide at $300{ }^{\circ} \mathrm{C}$ for analysis of TP in the sludge. All water parameters were measured by the spectrophotometric method using a continuous flow auto-analyzer (QuAAtro 2-HR, Bltec, Japan). For more detail, environmental parameters and analytical methods are summarized in Table 2.

\subsection{Nutrient Mass Balance Calculation}

The general mass balance was calculated according to Teichert-Coddington et al. [10] as Eq. (1):

$$
\begin{gathered}
\mathrm{S}_{\text {in }}+\mathrm{F}_{\text {in }}+\mathrm{Fert}_{\text {in }}+\mathrm{IPW}_{\text {in }}+\mathrm{WI}_{\text {in }}= \\
\mathrm{S}_{\text {out }}+\mathrm{PWH}_{\text {out }}+\mathrm{WD}_{\text {out }}+\mathrm{RS}_{\text {out }}+\mathrm{UN}
\end{gathered}
$$


Table 2 Summary methods for analyses of parameters in water and sludge, shrimp and shrimp feed samples.

\begin{tabular}{|c|c|}
\hline Sample parameters & Methods \\
\hline \multicolumn{2}{|l|}{ Water } \\
\hline Temperature $\left({ }^{\circ} \mathrm{C}\right)$ & Digital thermometer in situ \\
\hline Dissolved oxygen $(\mathrm{mg} / \mathrm{L})$ & Winkler method [1] \\
\hline $\mathrm{pH}$ & Potentiometric method [1] \\
\hline Alkalinity (mg/L) & Indophenol blue method [17] \\
\hline Salinity (ppt) & Electrical conductivity method \\
\hline $\mathrm{NH}_{4}^{+}-\mathrm{N}(\mathrm{mg} / \mathrm{L})$ & Indophenol blue method [17] \\
\hline $\mathrm{NO}_{3}-\mathrm{N}(\mathrm{mg} / \mathrm{L})$ & Colorimetric method [18] \\
\hline Total nitrogen $(\mathrm{TN})(\mathrm{mg} / \mathrm{L})$ & Digestion method [19] \\
\hline $\mathrm{PO}_{4}-\mathrm{P}(\mathrm{mg} / \mathrm{L})$ & Ascorbic acid method [18] \\
\hline Total phosphorus (TP) (mg/L) & Digestion and ascorbic acid method [18] \\
\hline \multicolumn{2}{|l|}{ Sludge, shrimp and shrimp feed } \\
\hline $\mathrm{TN}$ & Digestion method [8] \\
\hline TP & Digestion method [8] \\
\hline
\end{tabular}

where $S=$ shrimp, $\mathrm{F}=$ feed, Fert $=$ fertilizer, IPW $=$ initial pond water nutrients, WI $=$ intake water nutrients, $\mathrm{PWH}_{\mathrm{out}}=$ nutrients remaining at harvest, $\mathrm{WD}_{\text {out }}=$ nutrients in discharged water, $\mathrm{RS}_{\text {out }}=$ nutrients in sludge removed (dry weight) and UN = unaccounted nutrients.

The total amount of commercial shrimp feed used, quantity of sludge removed and yields of each pond were recorded. Fertilizer was not used in this study. Water intake and discharge volumes were estimated based on the measurement of water levels inside each pond. No drainage occurred during the production, and the intake water was to compensate for water losses during sludge removal. Inputs of nutrients through atmospheric rainfall and nitrogen fixation by blue-green algae were considered negligible $[1,7,8]$. The study took place in the spring, and water loss by evaporation was negligible.

\section{Results and Discussion}

\subsection{Water and Sludge Properties}

Table 3 shows the water parameters, which were measured daily on site. The commercial pelleted feed contained $6.02 \%$ N, $1.47 \%$ P and $11 \%$ water. Shrimp comprised $29.3 \%$ dry matter, $10.88 \% \mathrm{TN}$ and $1.33 \%$ TP in the whole body. The average volumes of water losses and compensation were $30 \%$ of total pond volume for $10 \mathrm{~d}$ or $2.45 \%$ daily over the period. Nitrogen $\left(\mathrm{NH}_{4}-\mathrm{N}, \mathrm{NO}_{3}-\mathrm{N}\right.$, and $\left.\mathrm{TN}\right)$ and phosphorus $\left(\mathrm{PO}_{4}-\mathrm{P}\right.$ and $\left.\mathrm{TP}\right)$ concentrations in the intake and discharge water increased with increasing length of culture (Table 4). These data are in agreement with those of Ma et al. [4], who also showed that nutrient concentrations in ponds increased with increasing culture period. For example, TN concentrations increased from $0.20 \mathrm{mg} / \mathrm{L}$ to $0.51 \mathrm{mg} / \mathrm{L}$, and $\mathrm{TP}$ showed the same trend from $0.25 \mathrm{mg} / \mathrm{L}$ to $0.34 \mathrm{mg} / \mathrm{L}$ in the first $20 \mathrm{~d}$ to final day, respectively. The concentrations of $\mathrm{TN}$ and TP were much higher in discharge water, from $2.5 \mathrm{mg} / \mathrm{L}$ to $3.2 \mathrm{mg} / \mathrm{L}$ and 0.38 $\mathrm{mg} / \mathrm{L}$ to $1.47 \mathrm{mg} / \mathrm{L}$, respectively. On average, total food added and shrimp harvested per hectare of shrimp pond per cycle were 10,747.3 $\mathrm{kg}$ and 7,046.1 $\mathrm{kg}$, respectively. Farm staff removed an average of $12,709( \pm 3,050) \mathrm{kg} / \mathrm{ha} /$ cycle of sludge (dry weight) with concentrations of TN and TP of $8.9 \mathrm{~g} / \mathrm{kg}$ and 6.2 $\mathrm{g} / \mathrm{kg}$, respectively.

\subsection{Nutrient Mass Balances}

The mass balances of $\mathrm{TN}$ and $\mathrm{TP}$ are shown in Table 5. The input source was mainly shrimp feed, which accounted for more than $90 \%$ of nutrient input. The present results may be comparable with other 
Table 3 Water quality parameters in ponds $(n=4)$.

\begin{tabular}{ll}
\hline Temperature at 7:30/14:00 $\left({ }^{\circ} \mathrm{C}\right)$ & $28.9 \pm 0.7 / 30.3 \pm 0.6$ \\
\hline Dissolved oxygen $(\mathrm{DO})(\mathrm{mg} / \mathrm{L})($ at $7: 30 / 14: 00)$ & $6.2 \pm 0.1 / 6.5 \pm 1.3$ \\
$\mathrm{pH}($ at $7: 30 / 14: 00)$ & $7.8 \pm 0.2 / 8.0 \pm 0.3$ \\
Alkalinity $(\mathrm{mg} / \mathrm{L})$ & $143.6 \pm 20.6$ \\
Salinity $(\mathrm{ppt})$ & $28.9 \pm 1.9$ \\
\hline
\end{tabular}

Table 4 Nutrient concentrations of intake and discharge water and sludge samples.

\begin{tabular}{|c|c|c|}
\hline Water samples & Intake water & Discharge water \\
\hline \multicolumn{3}{|l|}{$\mathrm{NH}_{4}{ }^{+}-\mathrm{N}(\mathrm{mg} / \mathrm{L})$} \\
\hline $20 \mathrm{~d}$ & $0.15 \pm 0.01$ & $0.30 \pm 0.02$ \\
\hline $30 \mathrm{~d}$ & $0.14 \pm 0.00$ & $1.50 \pm 0.32$ \\
\hline $40 \mathrm{~d}$ & $0.33 \pm 0.01$ & $2.40 \pm 0.02$ \\
\hline $49 \mathrm{~d}$ & $0.33 \pm 0.06$ & $2.90 \pm 0.12$ \\
\hline \multicolumn{3}{|l|}{$\mathrm{NO}_{3}-\mathrm{N}(\mathrm{mg} / \mathrm{L})$} \\
\hline $20 \mathrm{~d}$ & $0.025 \pm 0.00$ & $0.13 \pm 0.01$ \\
\hline $30 \mathrm{~d}$ & $0.021 \pm 0.00$ & $0.28 \pm 0.01$ \\
\hline $40 \mathrm{~d}$ & $0.036 \pm 0.01$ & $0.34 \pm 0.01$ \\
\hline $49 \mathrm{~d}$ & $0.030 \pm 0.01$ & $0.43 \pm 0.00$ \\
\hline \multicolumn{3}{|l|}{$\overline{\mathrm{TN}}(\mathrm{mg} / \mathrm{L})$} \\
\hline $20 \mathrm{~d}$ & $0.20 \pm 0.17$ & $2.50 \pm 0.53$ \\
\hline $30 \mathrm{~d}$ & $0.24 \pm 0.25$ & $2.00 \pm 0.70$ \\
\hline $40 \mathrm{~d}$ & $0.40 \pm 0.03$ & $3.01 \pm 0.12$ \\
\hline $49 \mathrm{~d}$ & $0.51 \pm 0.09$ & $3.18 \pm 0.78$ \\
\hline \multicolumn{3}{|l|}{$\mathrm{PO}_{4}-\mathrm{P}(\mathrm{mg} / \mathrm{L})$} \\
\hline $20 \mathrm{~d}$ & $0.03 \pm 0.02$ & $0.22 \pm 0.07$ \\
\hline $30 \mathrm{~d}$ & $0.04 \pm 0.01$ & $0.30 \pm 0.02$ \\
\hline $40 \mathrm{~d}$ & $0.08 \pm 0.00$ & $0.40 \pm 0.07$ \\
\hline $49 \mathrm{~d}$ & $0.07 \pm 0.01$ & $0.76 \pm 0.01$ \\
\hline \multicolumn{3}{|l|}{$\mathrm{TP}(\mathrm{mg} / \mathrm{L})$} \\
\hline $20 \mathrm{~d}$ & $0.25 \pm 0.10$ & $0.38 \pm 0.07$ \\
\hline $30 \mathrm{~d}$ & $0.28 \pm 0.04$ & $0.49 \pm 0.05$ \\
\hline $40 \mathrm{~d}$ & $0.21 \pm 0.09$ & $0.64 \pm 0.01$ \\
\hline $49 \mathrm{~d}$ & $0.34 \pm 0.03$ & $1.47 \pm 0.05$ \\
\hline Sludge samples & $\mathrm{TN}(\mathrm{mg} / \mathrm{L})$ & $\mathrm{TP}(\mathrm{mg} / \mathrm{L})$ \\
\hline $20 \mathrm{~d}$ & $7.3 \pm 0.28$ & $4.74 \pm 0.01$ \\
\hline $30 \mathrm{~d}$ & $8.3 \pm 0.28$ & $5.06 \pm 0.00$ \\
\hline $40 \mathrm{~d}$ & $9.25 \pm 0.07$ & $7.37 \pm 0.00$ \\
\hline $49 \mathrm{~d}$ & $10.75 \pm 0.35$ & $7.66 \pm 0.01$ \\
\hline
\end{tabular}

intensive shrimp ponds in Thailand $[16,20]$, where the majority source of the nutrient input in the pond (more than 90\%) was from commercial pelleted feed. Similarly, Jackson et al. [7] reported nitrogen mass balance from intensive shrimp farm in Australia where $90 \%$ of $\mathrm{N}$ input was from shrimp feed. Post-larvae were reared in a greenhouse for one month before being transferred to grow-out ponds, where shrimp contributed up to $1.8 \%$ of $\mathrm{N}$ and $0.9 \%$ of $\mathrm{P}$ input. For the sinks of $\mathrm{N}$ in the ponds, harvested shrimp was the largest with $37.5 \%$ of total input, but not of P (18.3\%). The assimilated shrimp harvest nutrients from the total inputs were higher than those in other studies [16, 20]. In an intensive shrimp system, Xia et al. [21] reported that $32.9 \% \mathrm{~N}$ and $14.2 \% \mathrm{P}$ from total inputs were recovered from harvested shrimp, just slightly lower 
Table 5 Estimation of nutrient mass balances in shrimp ponds $(n=4)$.

\begin{tabular}{lllll}
\hline Nutrients & $\mathrm{TN}(\mathrm{kg} / \mathrm{ha} /$ cycle $)$ & $\%$ & $\mathrm{TP}(\mathrm{kg} / \mathrm{ha} / \mathrm{cycle})$ & $\%$ \\
\hline Input & & & & 0.9 \\
\hline $\mathrm{S}_{\text {in }}$ & $11.0 \pm 0.2$ & 1.8 & $1.3 \pm 0.3$ & 0.0 \\
Fert $_{\text {in }}$ & 0.0 & 0.0 & 0.0 & 94.9 \\
$\mathrm{~F}_{\text {in }}$ & $575.8 \pm 170.9$ & 96.2 & $140.6 \pm 41.7$ & 4.2 \\
$\mathrm{IPW}_{\text {in }}+\mathrm{WI}_{\text {in }}$ & $11.5 \pm 0.0$ & 1.9 & $6.2 \pm 0.0$ & 100.0 \\
\hline Total & 598.4 & 100.0 & 148.2 & 11.6 \\
\hline Output & & & 18.3 \\
\hline PWH $_{\text {out }}+\mathrm{WD}_{\text {out }}$ & $78.4 \pm 5.5$ & 13.2 & $17.1 \pm 2.1$ & 53.2 \\
$\mathrm{~S}_{\text {out }}$ & $224.6 \pm 50.5$ & 37.5 & $27.2 \pm 6.1$ & 16.9 \\
$\mathrm{RS}_{\text {out }}$ & $113.1 \pm 27.1$ & 18.9 & $78.8 \pm 18.9$ & 100.0 \\
Un-accounted & $212.7 \pm 6.2$ & 30.4 & $25.0 \pm 17.9$ & 148.2 \\
\hline Total & 598.4 & 100.0 & & \\
\hline
\end{tabular}

TN: total nitrogen, TP: total phosphorus, $\mathrm{S}_{\mathrm{in}}$ : nutrients in postlarvae shrimp, Fert $_{\text {in }}$ : nutrients in fertilizer, $\mathrm{F}_{\mathrm{in}}$ : nutrients in shrimp feed, $\mathrm{IPW}_{\text {in }}$ : nutrients in pond water before shrimp stocking, $\mathrm{WI}_{\mathrm{in}}$ : nutrients in water intake, $\mathrm{PWH}_{\text {out }}$ : nutrients remaining in pond water after harvesting, $\mathrm{WD}_{\text {out }}$ : nutrients in drainage water, $\mathrm{S}_{\text {out }}$ : nutrients in shrimp harvest, $\mathrm{RS}_{\text {out }}$ : nutrients in removed sediment.

than those of the present study.

About $30.4 \% \mathrm{~N}$ and $16.9 \% \mathrm{P}$ of input were not accounted for measured losses. Nitrogen loss was attributed to denitrification and volatilization $[1,7,10$, 13]. While removed sludge retained the smallest proportion of $\mathrm{N}(18.9 \%)$, the largest quantity of $\mathrm{P}$ was trapped in removed sludge (53.2\%). Funge-Smith and Briggs [20] showed that sludge retained $24 \% \mathrm{~N}$ and up to $84 \% \mathrm{P}$ in intensive shrimp ponds in Thailand. Likewise, Hopkins et al. [9] reported 15\%-24\% N inputs for intensive ponds without sludge removal at the end of the season. Mariscal-Lagarda and Páez-Osuna [13] suggested that sludge accumulation was responsible for the sink of $\mathrm{P}$ in an integrated tank with shrimp and tomato.

In this study, the farm was operated without water exchange, so the pond gained only $1.9 \% \mathrm{~N}$ and $4.2 \%$ $\mathrm{P}$ from water intake. By contrast, approximately $13.2 \% \mathrm{~N}(78.4 \mathrm{~kg} / \mathrm{ha} /$ cycle) and $11.6 \% \mathrm{P}(17.1 \mathrm{~kg}$ ha/cycle) were lost from water discharge (during sludge removal). These values were in closed agreement with those from other literature, for instance, Funge-Smith and Briggs [20] reported 27\% $\mathrm{N}$ and $10 \% \mathrm{P}$ for the nutrient budget of discharged water. The proportions of $\mathrm{N}$ and $\mathrm{P}$ in discharge water of the present study are comparable to those of closed intensive systems, in which drainage water contained $14 \%-28 \% \mathrm{~N}$ and $12 \%-19 \% \mathrm{P}$ [16].

Table 6 indicates that $333.2 \mathrm{~kg} \mathrm{~N}(47 \mathrm{~kg} \mathrm{~N} /$ ton shrimp) and $113.1 \mathrm{~kg} \mathrm{P}$ (16 kg P/ton shrimp) of the nutrients for a hectare per cycle were lost to the surrounding environment. In other words, the authors' results noted that for $1 \mathrm{~kg}$ shrimp production needed $84.9 \mathrm{~g} \mathrm{~N}$ and $26.1 \mathrm{~g} \mathrm{P}$ from input sources, and $47.3 \mathrm{~g}$ $\mathrm{N}$ and $16.0 \mathrm{~g} \mathrm{P}$ were discharged into the environment. Similarly, Mariscal-Lagarda and Páez-Osuna [13] estimated that environmental losses of $1 \mathrm{~kg}$ of product harvested were $57 \mathrm{~g} \mathrm{~N}$ and $7.1 \mathrm{~g} \mathrm{P}$ for an integrated shrimp culture.

These results were different from those of semi-intensive and extensive shrimp systems, in which ponds gained nutrients mostly from water intake and fertilizers. Water exchange in these systems is greater (11\% of total pond volume per day) [8] than in an intensive system (little or no water exchange) [22]. Using fertilizers augments natural food organisms within a water body as a supplemental food for shrimp and balances the environmental conditions in ponds, because extensive and semi-intensive ponds usually do not have aerators. Islam et al. [11] reported that intake water and fertilizers accounted for $55 \%$ and $29 \%$ of total nitrogen inputs, respectively. By contrast, 
Table 6 Environmental losses of nutrients for different pond systems and management methods.

\begin{tabular}{|c|c|c|c|c|c|}
\hline \multirow{2}{*}{ Systems } & \multicolumn{2}{|c|}{$\mathrm{N}$} & \multicolumn{2}{|r|}{$\mathrm{P}$} & \multirow{2}{*}{-References } \\
\hline & In kg/ha/cycle & In $\mathrm{kg} /$ ton & In $\mathrm{kg} / \mathrm{ha} /$ cycle & In $\mathrm{kg} /$ ton & \\
\hline \multicolumn{6}{|l|}{ Intensive systems } \\
\hline P. monodon & 596 & 92 & 265 & 41 & {$[23]$} \\
\hline P. monodon & 764 & 112 & 213 & 31 & {$[24]$} \\
\hline P. monodon & 327 & 93.4 & - & - & {$[7]$} \\
\hline L. vannamei & 457 & 116 & 57 & 14.6 & {$[13]$} \\
\hline L. vannamei & 333.2 & 47 & 113.1 & 16 & This study \\
\hline \multicolumn{6}{|c|}{ Semi-intensive systems } \\
\hline L. vannamei & 66 & 36 & 22 & 12 & [1] \\
\hline L. vannamei & 19 & 29 & 8 & 12 & {$[10]$} \\
\hline P. monodon & 73 & 111 & 38 & 58 & [11] \\
\hline L. vannamei (FT) & 235 & 71 & 43 & 12 & {$[8]$} \\
\hline L. vannamei (FD) & 214 & 73 & 38 & 13 & {$[8]$} \\
\hline
\end{tabular}

FT: feeding tray, FD: feed dispersal device.

the sink of $\mathrm{N}$ from the shrimp harvest was only $12 \%$ and up to $78 \%$ from discharge water. The high amount of $\mathrm{N}$ in effluent was different from that of a water exchange procedure. However, Casillas-Hernández et al. [8] noted that more than $70 \% \mathrm{~N}$ and $50 \% \mathrm{P}$ inputs were from shrimp feed in semi-intensive shrimp ponds, respectively.

Table 6 showed that $40.3 \% \mathrm{TN}$ and $19.5 \%$ TP were recovered by shrimp harvest from feed added. These values were much higher than those of semi-intensive systems. For example, shrimp harvest in semi-intensive ponds assimilated only $12 \% \mathrm{TN}$ and $3.3 \%$ reported by TP Islam et al. [11]. Likewise, Páez-Osuna et al. [1] revealed that $35.5 \% \mathrm{TN}$ and $6.1 \%$ TP were recovered by shrimp harvest in semi-intensive ponds in Northwestern Mexico. These differences depended on nutrient sources in shrimp ponds. L. vannamei is an omnivorous species and it consumes diverse foods in a pond, including detritus and microorganisms. The distribution of natural foods in semi-intensive ponds is more available to shrimp, so the nutrients of inputs from other sources are converted to product (harvested shrimp).

The amounts of nutrients discharged from shrimp systems in this study are lower comparable with those in semi-intensive ponds reported by Islam et al. [11] (78 g N and $25 \mathrm{~g} \mathrm{P}$ ), but higher than the data of
Teichert-Coddington et al. [10], who estimated approximately $16.8 \mathrm{~g} \mathrm{~N}$ and $2.3 \mathrm{~g} \mathrm{P}$ discharge to the environment in a similar system. Environmental losses of nutrients were lower or intermediate, when the loads were expressed in both $\mathrm{kg} / \mathrm{ha} /$ cycle and $\mathrm{kg}$ of $\mathrm{N}$ or $\mathrm{P} /$ ton shrimp. These values were lower than that reported for other intensive shrimp ponds (Table 6). However, environmental losses of nutrients in the present study were much higher than those in semi-intensive shrimp ponds when expressed as $\mathrm{kg} / \mathrm{ha} /$ cycle, which indicated that higher intensity has a greater environmental impact of shrimp aquaculture.

Accordingly, the present study removed sludge periodically on days $20,30,40$, and 49 of shrimp culture to reduce the impacts of sludge on the pond environment. Consequently, pond water was maintained in good condition for shrimp, because dissolved oxygen and ammonia gas concentrations were $>6 \mathrm{mg} / \mathrm{L}$ and $<0.1 \mathrm{mg} / \mathrm{L}$, respectively. Furthermore, economic efficiency can be improved significantly when productivity is more than 7 tons/ha/cycle. Sludge and effluent from intensive shrimp culture and the environmental impacts of aquaculture are controlled by sludge removal, especially prevention of ground water contamination by seepage through the HDPE film at the bottom. 


\section{Conclusions}

The present study is the first mass balance of nutrients in intensive shrimp culture on sandy land using sludge management regime. The input source nutrient in the ponds was mainly from shrimp feed. While shrimp harvest was the largest sink of $\mathrm{N}$, the largest amount of $\mathrm{P}$ was accumulated in sludge. The results suggest that the shrimp culture in the system removed sludge periodically can be improved pond water quality. Concurrently, the environmental losses of $\mathrm{N}$ and $\mathrm{P}$ are reduced to minimize the risk of eutrophication of receiving waters.

\section{Acknowledgments}

The authors would like to thank the manager and staff members of C.P. Group of Thailand in the Phong Dien District, Thua Thien Hue Province, Vietnam (Farm II) for their permission to access facilities in farm. They also offer special thanks to Dr. Nguyen Quang Linh and Dr. Le Van Dan for their insightful comments on the early time of this study. In addition, the authors wish to thank to undergraduate students in the Faculty of Fisheries, Hue University of Agriculture and Forestry, for their contribution to sample collection and preservation. This study was supported by Okayama University, Research Grant for Encouragement of Students.

\section{References}

[1] Páez-Osuna, F., Guerrero-Galván, S. R., Ruiz-Fernández, A. C., and Espinoza-Angulo, R. 1997. "Fluxes and Mass Balances of Nutrients in a Semi-intensive Shrimp Farm in Northwestern Mexico.” Marine Pollution Bulletin 34 (5): 290-7.

[2] Velasco, M., Lawrence, A. L., and Castille, F. L. 1999. "Effect of Variations in Daily Feeding Frequency and Ration Size on Growth of Shrimp, Litopenaeus vannamei (Boone), in Zero-Water Exchange Culture Tanks." Aquaculture 179 (1-4): 141-8.

[3] Pillay, T. V. R. 2004. Aquaculture and the Environment, 2nd ed. Oxford, UK: Blackwell Publishing Ltd..

[4] Ma, Z., Song, X., Wan, R., and Gao, L. 2013. "A Modified Water Quality Index for Intensive Shrimp Ponds of Litopenaeus vannamei." Ecological Indicators
24: $287-93$.

[5] Food and Agriculture Organization of the United Nations (FAO). 1986. Shrimp Culture: Pond Design, Operation and Management. NACA Training Manual Series No. 2, Aquaculture Department, Southeast Asian Fisheries Development Center.

[6] IUCN and IISD. 2003. Expanding Shrimp Aquaculture on Sandy Land in Vietnam: Challenges and Opportunities. Hanoi: IUCN and IISD.

[7] Jackson, C., Preston, N., Thompson, P. J., and Burford, M. 2003. "Nitrogen Budget and Effluent Nitrogen Components at an Intensive Shrimp Farm." Aquaculture 218 (1-4): 397-411.

[8] Casillas-Hernández, R., Magallón-Barajas, F., Portillo-Clarck, G., and Páez-Osuna, F. 2006 "Nutrient Mass Balances in Semi-intensive Shrimp Ponds from Sonora, Mexico Using Two Feeding Strategies: Trays and Mechanical Dispersal." Aquaculture 258 (1-4): 289-98.

[9] Hopkins, J. S., Sandifer, P. A., and Browdy, C. L. 1994. "Sludge Management in Intensive Pond Culture of Shrimp: Effect of Management Regime on Water Quality, Sludge Characteristics, Nitrogen Extinction and Shrimp Production.” Aquacultural Engineering 13 (1): 11-30.

[10] Teichert-Coddington, D. R., Martinez, D., and Ramírez, E. 2000. "Partial Nutrient Budgets for Semi-Intensive Shrimp Farms in Honduras." Aquaculture 190 (1-2): 139-54.

[11] Islam, S. M., Sarker, J., Yamamoto, T., Wahab, A., and Tanaka, M. 2004. "Water and Sediment Quality, Partial Mass Budget and Effluent $\mathrm{N}$ Loading in Coastal Brackishwater Shrimp Farms in Bangladesh." Marine Pollution Bulletin 48 (5-6): 471-85.

[12] Wahab, M. A., Bergheim, A., and Braaten, B. 2003. "Water Quality and Partial Mass Budget in Extensive Shrimp Ponds in Bangladesh." Aquaculture 218 (1-4): 413-23.

[13] Mariscal-Lagarda, M. M., and Páez-Osuna, F. 2014. "Mass Balances of Nitrogen and Phosphorus in an Integrated Culture of Shrimp (Litopenaeus vannamei) and Tomato (Lycopersicon esculentum Mill) with Low Salinity Groundwater: A Short Communication." Aquacultural Engineering 58: 107-12.

[14] Frignani, M., Piazza, R., Bellucci, L. G., Cu, N. H., Zangrando, R., Albertazzi, S., Moret, I., Romano, S., and Gambaro, A. 2007. "Polychlorinated Biphenyls in Sediments of the Tam Giang-Cau Hai Lagoon, Central Vietnam." Chemosphere 67 (9): 1786-93.

[15] Hung, L. T., and Quy, O. M. 2013. On-Farm Feeding and Feed Management in Whiteleg Shrimp (Litopenaeus vannamei) Farming in Vietnam. FAO Fisheries and Aquaculture Technical Paper 583. 


\section{A Case Study in the Tam Giang Lagoon, Central Vietnam}

[16] Thakur, D. P., and Lin, C. K. 2003. "Water Quality and Nutrient Budget in Closed Shrimp (Penaeus monodon) Culture Systems." Aquacultural Engineering 27 (3): 159-76.

[17] Parsons, T. R., Maita, Y., and Lalli, C. M. 1992. A Manual of Chemical and Biological Methods for Seawater Analysis. New York, NY, USA: Pergamon Press, 173.

[18] American Public Health Association (APHA). 2005 Standard Methods for the Examination of Water and Wastewater, 21st ed.. Washington, D.C., USA: APHA.

[19] Grasshoff, K., Kremling, K., and Ehrhardt, M. 1999. Methods of Seawater Analysis. Verlag, Weinheim, Germany: Wiley-VCH.

[20] Funge-Smith, S. J., and Briggs, M. R. P. 1998. "Nutrient Budgets in Intensive Shrimp Ponds: Implications for Sustainability." Aquaculture 164: 117-33.
[21] Xia, L. Z., Yang, L. Z., and Yan, M. C. 2004. "Nitrogen and Phosphorus Cycling in Shrimp Ponds and the Measures for Sustainable Management." Environmental Geochemistry and Health 26 (2): 245-51.

[22] Ray, A. J., Dillon, K. S., and Lotz, J. M. 2011. "Water Quality Dynamics and Shrimp (Litopenaeus vannamei) Production in Intensive, Mesohaline Culture Systems with Two Levels of Biofloc Management." Aquacultural Engineering 45 (3): 127-36.

[23] Briggs, M. R. P., and Funge-Smith, S. J. 1994. "A Nutrient Budget of Some Intensive Marine Shrimp Ponds in Thailand." Aquaculture and Fisheries Management 25 (8): 789-811.

[24] Robertson, A. I., and Phillips, M. J. 1995. "Mangroves as Filters of Shrimp Pond Effluent: Predictions and Biogeochemical Research Needs.” Hydrobiologia 295 (1): 311-21. 